\title{
COMPREHENSIVE RADON CONCENTRATION MEASUREMENTS IN CAVES LOCATED IN THE AREA OF MECSEK MOUNTAINS (HUNGARY)
}

\section{MERJENJE KONCENTRACIJ RADONA V JAMAH GOROVJA MECSEK (MADŽARSKA)}

\author{
Gabriella KOLTAI ${ }^{1}$, János ORSZÁG ${ }^{2}$, Zoltán TEGZES² \& Ilona BÁRÁNY-KEVEI ${ }^{1}$
}

\begin{abstract}
UDC 911:551.44:539.16 (439)

Gabriella Koltai, János Ország, Zoltán Tegzes \& Ilona BárányKevei: Comprehensive Radon Concentration Measurements in Caves Located in the Area of Mecsek Mountains

Radon concentration has been investigated in nine caves of the Mecsek Mountains, Hungary. Apart from radon concentration, underground temperature and pressure were detected by DATAQUA monitoring devices. Our primary aim was to gain information about both the radon concentration levels and the convectional systems of these caves in order to study the characteristics of the research area. In addition, we intended to detect any differences between the caves either on the basis of the previous measurements or on account of their topo-morphological location. Data were comprehensively analyzed in relation to surface temperature and atmospheric pressure. The collected data showed that the caves located in the research area have particularly high radon concentrations. The highest values were measured in valley floor-positioned caves whereas the lowest ones in hilltop-positioned caves. In four cases the air convection systems of the studied caves differed from what would have been indicated by their topo-morphological location. In our study we summarize the convectional laws and uniqueness of the caves investigated.
\end{abstract}

Keywords: radon concentration, air convection, cave, topomorphological location, Mecsek Mountains, Hungary.
Izvleček

UDK 911:551.44:539.16 (439)

Gabriella Koltai, János Ország, Zoltán Tegzes \& Ilona BárányKevei: Merjenje koncentracij radona $v$ jamah gorovja Mecsek (Madžarska)

$\mathrm{V}$ devetih jamah gorovja Mecsek na Madžarskem smo merili koncentracijo radona, temperaturo in tlak zraka. Naš namen je bil zbrati podatke o podzemnih koncentracijah radona in jih obravnavati z vidika podzemnih konvekcijskih zračnih tokov. Opazovali smo razlike v vrednostih med jamami, pri čemer glede na predhodne meritve in glede na topografski položaj jam. V analizo smo vključili tudi podatke o temperaturi in tlaku površja. Koncentracije radona v opazovanih jamah so v splošnem zelo visoke, pri čemer smo najvišje koncentracije namerili v jamah, ki ležijo topografsko nizko (v dolinah), najnižje pa v jamah, ki so topografsko visoko (blizu vrhov). V štirih jamah se je izkazalo, da konvekcijski tokovi ne tečejo v smereh, kot bi jih narekoval njihov topografski položaj.

Ključne besede: koncentracija radona, zračna konvekcija, jama, topomorfološka lokacija, gorovje Mecsek, Madžarska.

\section{INTRODUCTION}

Radon transport measurements are of vital importance in excavational speleology owing to the fact that radon $\left({ }^{222} \mathrm{Rn}\right)$ is an excellent tracer of underground airflow
(Hakl 1997; Dezső \& Molnár 2001). As carbonate rocks are particularly fractured in the case of limestone caves, radon transport measurements are particularly useful

\footnotetext{
${ }^{1}$ University of Szeged, Department of Climatology and Landscape Ecology, 6722 Szeged, Egyetem u. 2, Hungary, emails: keveibar@earth.geo.u-szeged.hu, gabikoltai@gmail.com

${ }^{2}$ Mecsekérc ZRt. 7633 Pécs, Esztergál L. u. 19, Hungary, emails: orszagjanos@mecsekerc.hu, tegzeszoltan@mecsekerc.hu

Received/Prejeto: 01.03.2010
} 
in cave climate investigations. From the radon concentration and its variation in a given subsurface airspace, it can be ascertained to what extent this particular part of the cave communicates both with other passages and with the surface (Hakl et al.1997b). The analysis of these processes can contribute to the exploration of undiscovered passages.

As Dezsö et al. (2001) has pointed out the primary source of radon in caves is clay deposits, which fill in the passages. Since radon is an inert gas and has a 3.8-day half-life it can diverge from its parent substance. The migration from its parent is first and foremost governed by temperature, rock porosity and humidity, while rapid atmospheric pressure changes and air movements caused by temperature differences are considered to be secondary factors (Papp et al. 2004).

In the study area radon concentration research on cave air started in 1995. Since then several caves have been monitored in the region of Orfü and Abaliget, of which nine were selected on the basis of their topomorphological location. Szuadó, Trió, Gilisztás, Pietró,
Tüskés, Sózó, Vadetetős, Upper Szajha and Aktív caves were involved in the research. Our primary intention was to gain information about both the radon concentration levels and the convectional systems of these caves in order to study the characteristics of the research area. In addition, we aimed to detect if there were differences between the caves either on the basis of previous measurements or on account of their morphological location. We were also determined to enquire to what extent radon transport measurements confirm the convectional models of the given caves, created on the basis of their morphological location.

Caves in the valley floor were expected to be at the highest concentration, whereas the hilltop caves were assumed to be at the lowest concentration levels. Moreover, on the basis of air convection models caves belonging to the first category were assumed to be characterized by high summer and low winter periods while the ones belonging to the second category were supposed to have low summer and high winter intervals.

\section{MATERIAL AND METHODS}

\section{THE STUDY AREA}

The geological structure of Western Mecsek is characterized by an anticlinal with an eastern-western line of strike. The rocks of the anticlinal are particularly stressed, fragmented, and moved by faults. The uplifted middle part of the anticlinal is built up by Permian and Triassic sandstones with aleurolite and conglomerate intercalations (Kővágószőlős Sandstone Formation, Jakabhegy Sandstone Formation; Fülöp 1994). On the northern limb a Triassic sequence superimposes to these beds in line with the strike of the anticlinal axis. The initial Triassic sandstones are changed by aleurolites (Patacs Aleurolite Formation). These beds are followed by argillaceous limestone strata rich in evaporates, then by dolomites (Hetvehely Dolomite Formation) and laminated black limestones. The next thin dolomite stratum (Rókahegy Dolomite Formation) is overlaid by well-karstifiable Anisian limestones (Lapis Limestone Formation, Zuhánya Limestone Formation, Csukma Dolomite Formation; Barta \& Tarnai 1999).

The investigated caves are situated on the large karst block located between the Abaliget-Mecsekrákos fracture and Misina in a $40 \mathrm{~km}^{2}$ territory. The area is divided by the drainage basins of eight efflux caves. Three of the analyzed caves (Vadetetős, Upper Szajha and Aktív caves) are hydrologically connected to Abaligeti Spring Cave; four (Szuadó, Trió, Gilisztás and Sózó caves) to Vízfö Spring Cave. Owing to the presence of a bifurcation zone it is uncertain whether Pietró and Tüskés caves belong to the subsurface drainage basin of Kispaplika or Mészégető efflux cave. All the investigated caves are small; they are neither longer than $300 \mathrm{~m}$ nor deeper than $65 \mathrm{~m}$. The entrances of Aktív, Sózó, Szuadó, Gilisztás and Trió caves are situated in a valley. Szajha and Vadetetös caves have hillside positions while Pietró and Tüskés caves are located on the top of a hill (Fig. 1). There is a high rate of non-karstic rocks on the drainage basins, so uranium-rich sediments that are the outcome of the chemical weathering of Jakabhegy Standstone Formation are carried by water.

\section{DATA AND METHODS}

Both single-and multi-parameter DATAQUA detectors were used for data collection (Fig. 2). While single-parameter detectors documented only the radon concentration of cave air, multi-parameter devices recorded underground temperature and pressure, as well. The exposure time of the detectors was set to one hour.

Apart from a single measurement, all the detectors were placed either in the entrance or in the end zones of 


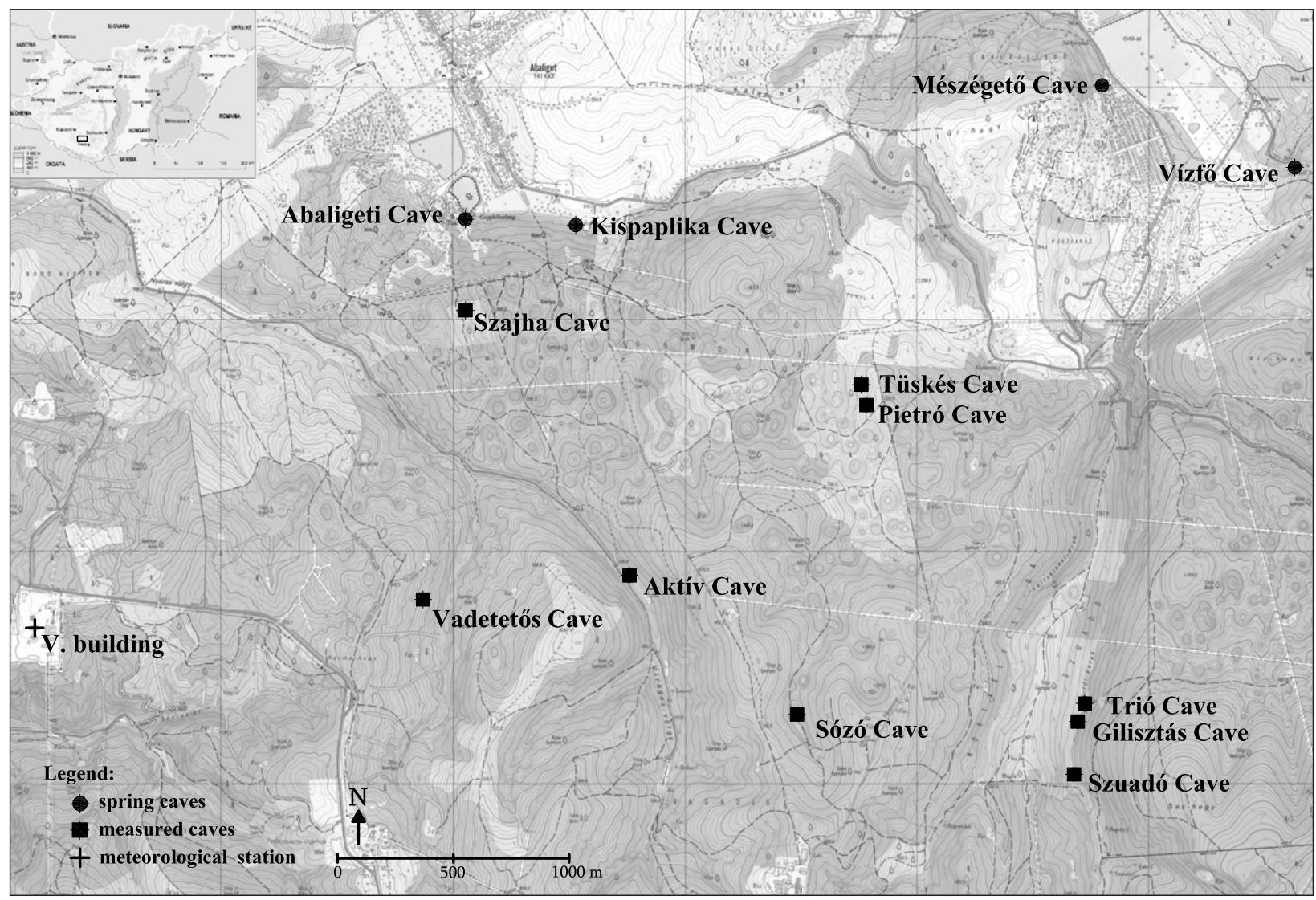

Fig. 1: The study area, Western Mecsek, Hungary.

the investigated caves ${ }^{1}$. The measurement periods usually lasted for 4-6 months: nevertheless, the detectors were checked regularly. Having only a few DATAQUA equipments, simultaneous measurements could be carried out only in Vadetetős Cave.

The underground records were comprehensively analyzed and graphed in relation to external temperature and atmospheric pressure ${ }^{2}$. During data evaluation the mean values of subsurface radon concentration, temperature and pressure were counted. Concerning radon

\footnotetext{
1 Detectors were placed in the entrance zones because one of our aims was to observe how the direction of the airflow changes inside the caves. End zones were measured in order to gain information about possible new passages, as well as to know how high are the concentration levels the cave is characterized by.

${ }^{2}$ Meteorological data were collected at the station located on the top of V. mining building (Fig. 1). This is the closest meteorological station in the research area that provides appropriate data. Surface parameters were recorded at ten minutes frequency.
}

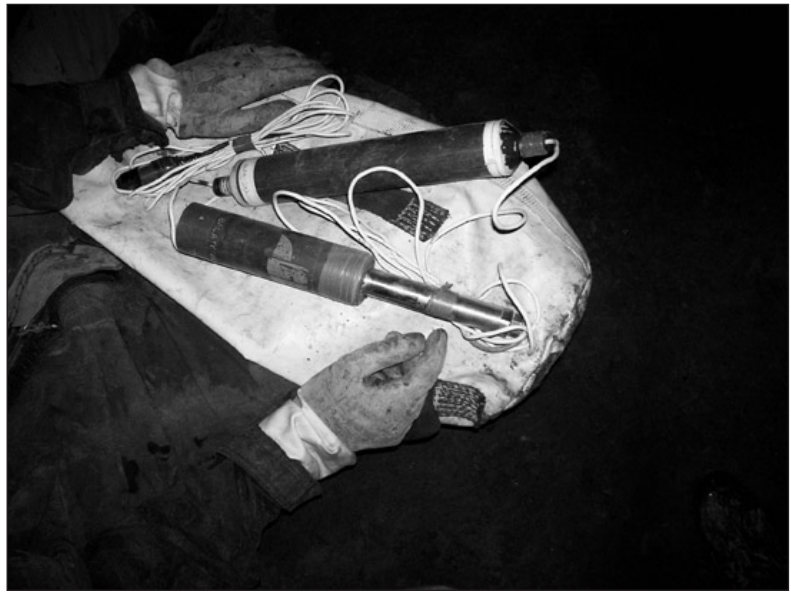

Fig. 2: The detector (Photo: G. Koltai).

concentration high and low periods were investigated in each cave separately, as well as the direction of underground airflow. To provide an answer for the question of the extent to which the various factors influence the variation of radon concentration both correlation and regression analyses were used. Unfortunately, these methods did not give appropriate results. 


\section{RESULTS AND DISCUSSION}

The analyzed data showed that the radon concentration of cave air was particularly high in the Mecsek Mountains. The highest values were observed in caves which have their entrances on a valley floor, and the lowest ones were recorded in caves which open up on the top of a hill. Hakl et al. (1997a) claims that in karstic caves the annual average radon concentration varies between 0.1 and $20 \mathrm{kBq} \mathrm{m}^{-3}$ with an arithmetic average of $2.8 \mathrm{kBq} \mathrm{m}^{-3}$. In Hungary the average annual concentration ranges between 0.3 and $10.6 \mathrm{kBq} \mathrm{m}^{-3}$ (Hakl 1997), while in Aktív Cave it reached $15 \mathrm{kBq} \mathrm{m}^{-3}$. During a one-week measurement in Trió Cave the mean radon concentration reached even $56.7 \mathrm{kBq} \mathrm{m}^{-3} .^{3}$ Surprisingly, particularly high radon levels were occasionally detected in Vadetetős Cave. Moreover, significant changes have happened concerning the high and low periods. No significant changes occurred on the basis of previous longterm measurements in the investigated caves, except Vadetetös Cave. Concerning the convectional models of the investigated caves, some interesting phenomena were found. In the following, owing to the limited length of the paper only those caves will be discussed in detail that have a different airflow system from what would be normally indicated by their topo-morphological position. In order to provide a basis for comparison the results of Aktív, Sózó and Pietró caves will be presented since they are characterized by the usual high and low concentration periods.

\section{CAVES IN A VALLEY FLOOR POSITION}

\section{Aktív and Sózó caves}

Concerning radon levels both caves are characterized by summer maxima and winter minima (Tab. 1). In Sózó Cave the fluctuation of radon levels during spring and autumn is particularly high. In spite of the strong airflow radon concentration is very high, and it responds quickly to weather changes, which suggests the openness of Sózó Cave as well as its active communication with a larger passage system.

The high summer values that occur in Aktív Cave are related to its poor ventilation. The passages are particularly narrow and crumbling due to the fact that the cave developed at a bedding plane. Fractures going towards the surface are filled with sandstone and limestone debris. Although the continuation of the passage can be seen at the current endpoint no draught can be felt in any time of the year.

\section{Szuadó Cave}

Szuadó Cave, which was formed at the border of the Viganvár Limestone Member and Rókahegy Dolomite Formation (Barta \& Tarnai 1999), is the southernmost sinkhole in the Szuadó valley. The first detection period started in 2007 at Sára Spring. ${ }^{4}$

After the detector was set, the radon level increased gradually from $14 \mathrm{kBq} \mathrm{m}^{-3}$ to $55 \mathrm{kBq} \mathrm{m}^{-3}$ (Fig. 3) with a mean concentration of $30.8 \mathrm{kBq} \mathrm{m}^{-3}$. This high level can originate either in the radon-rich air coming from the Great Shaft or in the presence of Sára Spring, or it can be caused by their cumulative effect. There is a $6-8 \mathrm{~m}$ thick clay layer in the Great Shaft. As the primary source

Tab 1: The nature of radon concentration changes in valley floor positioned caves.

\begin{tabular}{|c|c|c|c|c|c|}
\hline \multirow[t]{2}{*}{$\begin{array}{l}\text { Name of the } \\
\text { cave }\end{array}$} & \multirow[t]{2}{*}{$\begin{array}{l}\text { Place of the } \\
\text { detector }\end{array}$} & \multirow[t]{2}{*}{ Period } & \multicolumn{2}{|c|}{$\begin{array}{c}\text { Mean }{ }^{222} R n \text { concentration } \\
{\left[\mathrm{kBq} \mathrm{m}^{-3}\right]}\end{array}$} & \multirow{2}{*}{$\begin{array}{c}\text { Measured }{ }^{222} R n \\
\text { (maximum / minimum) } \\
{\left[k B q m^{-3}\right]}\end{array}$} \\
\hline & & & summer & winter & \\
\hline Aktív & entrance zone & $2000-2001$ & 26.5 & 4.05 & $269(37.66 / 0.14)$ \\
\hline Gilisztás & Csipkés Shaft & 2008 & - & 1.3 & $137(19.18 / 0.14)$ \\
\hline Sózó & entrance zone & $1999-2002$ & $19-20$ & $1-2$ & $25(25 / 1)$ \\
\hline \multirow{2}{*}{ Szuadó } & Sára Spring & \multirow{2}{*}{$2007-2008$} & 30.8 & - & \multirow{2}{*}{32.9 (54.94 / 1.64) } \\
\hline & entrance zone & & - & 25.35 & \\
\hline Trió cave & end zones & $2006-2007$ & 7.6 & 10.5 & $16.25(56.88 / 3.5)$ \\
\hline
\end{tabular}

${ }^{3}$ However, during a spot measurement, even three times higher values were recorded by Gunn (1991) in Giants Hole, Derbyshire Pea District, $155 \mathrm{kBq} \mathrm{m}^{-3}$ as cited by Hakl et al. (1997a).
${ }^{4}$ The measurement point is situated in the second zone of the cave with a wider passage section. A spring with a constant water discharge of $5 \mathrm{l} / \mathrm{min}$ can be found here. 


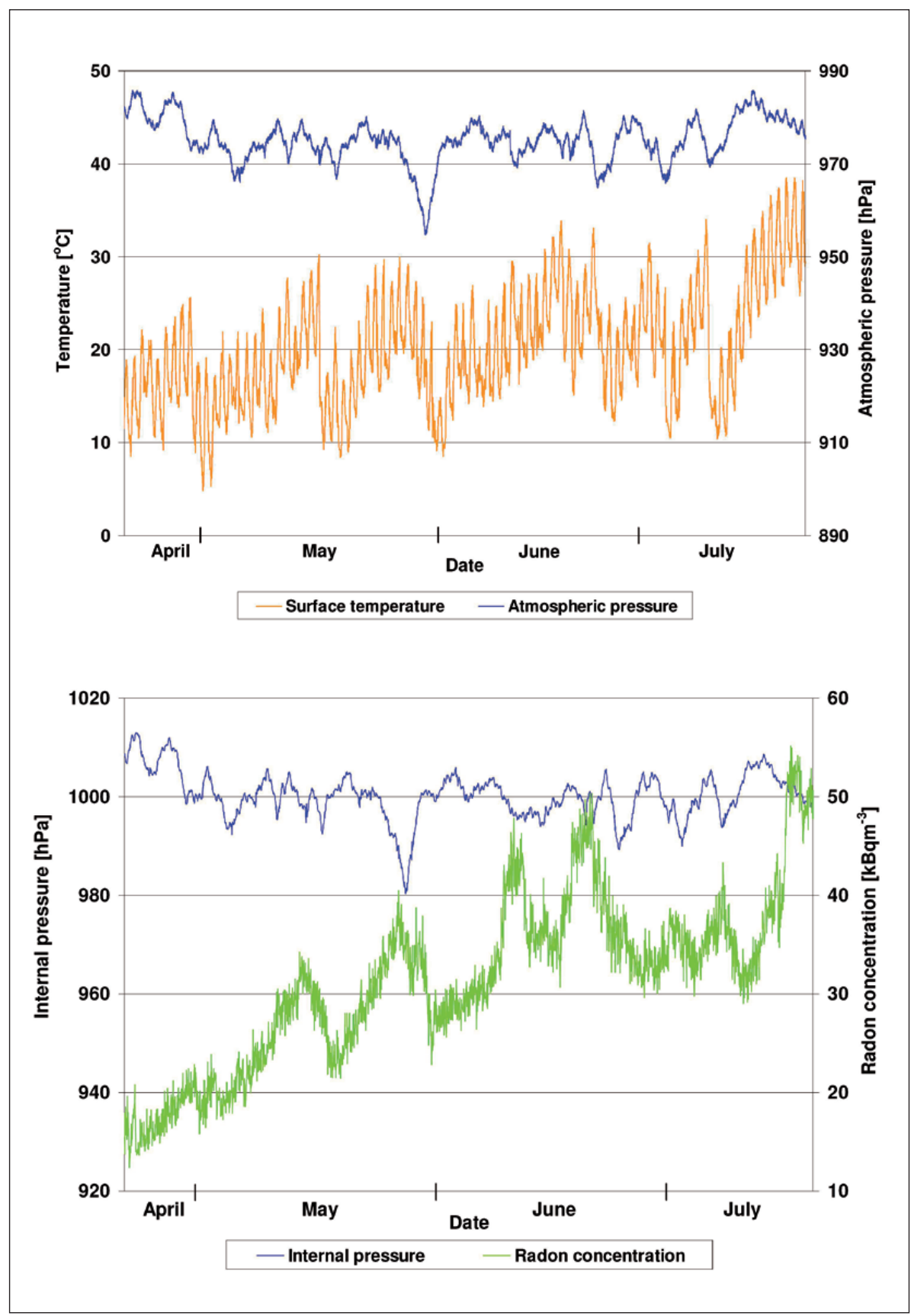

Fig. 3: Radon measurements at Sára Spring in Szuadó Cave compared with external temperature and atmospheric pressure, 2008.

of radon in caves is clay deposits (Dezső et al. 2001) the air of the Great Shaft is presumably rather rich in radon. Moreover, water coming out in Sára Spring may contain plenty of dissolved radon gas (Dezső et al. 2001), which can get into the air.

In January 2008 a multi-parameter device was set over the Post-box, which is situated after the artificial entrance of the cave. The measuring period involved both wintertime and springtime. Radon data varied between $1.6 \mathrm{kBq} \mathrm{m}^{-3}$ and 48.6 $\mathrm{kBq} \mathrm{m}^{-3}$, with a mean value of $23.5 \mathrm{kBqm}^{-3}$ (Fig. 4). In contrast with the measurement at Sára Spring the detected radon values at Postbox followed the changes of external temperature indirectly and the fluctuations of atmospheric pressure directly. The radon concentration started to decrease when the external temperature exceeded $10^{\circ} \mathrm{C}$.

All the investigations done in the deeper zone of caves with a valley floor position showed that radon levels directly followed external temperature, which contradicts the results of Post-box. Previously, the artificial entrance of Szuadó Cave was believed to generate a self-circuit airflow system by functioning as a chimney. However, as this self-circulation happens within a short passage section it would indicate much lower concentration values than the recorded ones.

\section{CAVES IN A HILLSIDE POSITION}

Both Upper Szajha and Vadetetös caves have special air convectional systems. Szajha Cave has no maxima or minima period, while in Vadetetös Cave not only has the direction of airflow changed, but also the difference between high and low concentration periods has become less significant (Tab. 2).

\section{Upper Szajha Cave}

The entrance of Upper Szajha Cave can be found approximately 350 metres to the south from the mouth of Abaligeti Spring Cave. The cave is in a convectional 
Tab 2: The nature of radon concentration changes regarding caves in a hillside position.

\begin{tabular}{|c|c|c|c|c|c|}
\hline \multirow[t]{2}{*}{$\begin{array}{l}\text { Name of the } \\
\text { cave }\end{array}$} & \multirow[t]{2}{*}{$\begin{array}{l}\text { Place of the } \\
\text { detector }\end{array}$} & \multirow[t]{2}{*}{ Period } & \multicolumn{2}{|c|}{$\begin{array}{c}\text { Mean }{ }^{222} \mathrm{Rn} \text { concentration } \\
{\left[\mathrm{kBq} \mathrm{\textrm {m } ^ { - 3 } ]}\right.}\end{array}$} & \multirow{2}{*}{$\begin{array}{c}\text { Measured }{ }^{222} R n \\
\text { (maximum / minimum) } \\
{\left[k B q m^{-3}\right]}\end{array}$} \\
\hline & & & summer & winter & \\
\hline $\begin{array}{l}\text { Upper } \\
\text { Szajha }\end{array}$ & $\begin{array}{l}\text { entrance zone } \\
(-14 m \text { deep) }\end{array}$ & $2003-2004$ & 1.1 & 0.4 & $101(10.1 / 0.1)$ \\
\hline \multirow{3}{*}{ Vadetetős } & \multirow[t]{2}{*}{ entrance zone } & $2003-2004$ & 3.6 & 15 & $584(58.4 / 0.1)$ \\
\hline & & $2007-2008$ & 2.71 & 2 & $231.3(23.13 / 0.1)$ \\
\hline & end zone & $2007-2008$ & 11.8 & 17.4 & $17.13(35.98 / 2.1)$ \\
\hline
\end{tabular}

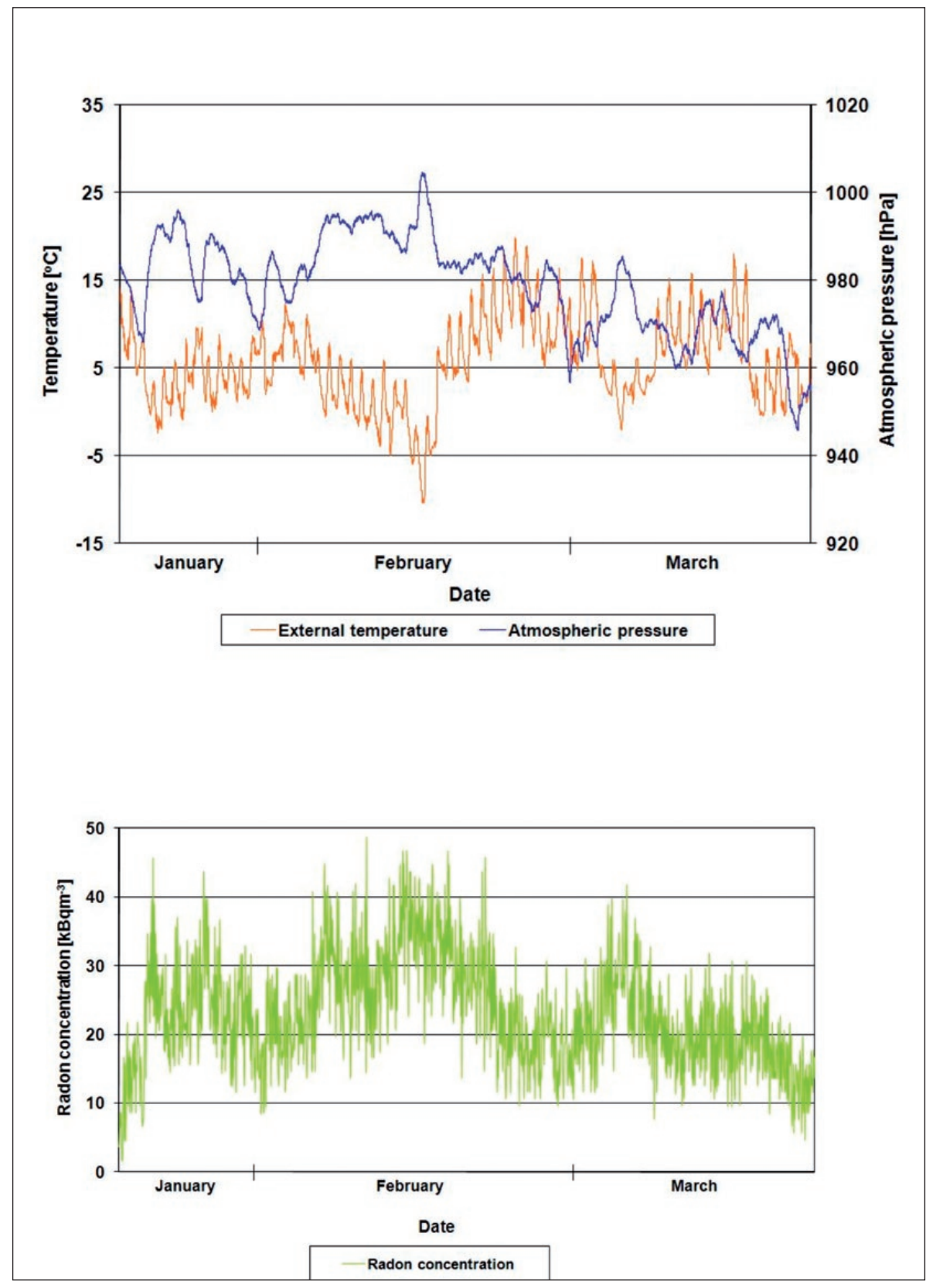

Fig. 4: Radon measurements at Post-box in Szuadó Cave compared with external temperature and pressure. connection with Lower Szajha Cave. ${ }^{5}$ The monitoring time lasted for three years.

During the data evaluation an interesting phenomenon was discovered: unlike other caves, neither high nor low periods could be observed, the fluctuation of radon values was the only significant difference between the seasonal data. In summer, for instance on $17^{\text {th }}$ June or $12^{\text {th }}$ July 2004, the radon concentration rose abruptly (Fig. 5). Such spikes could be seen on the graphs when atmospheric pressure decreased and external temperature went below $9-12^{\circ} \mathrm{C}$. Pressure drops alone generated only small increases. For a more significant concentration rise external temperature had to go under the critical value range $\left(9-12^{\circ} \mathrm{C}\right)$ as well. In an ideal case, this would suggest a hilltop location entrance type.

In winter, instead of the expected higher levels, the radon concentration re-

5 The two caves are connected through a narrow debris zone, which is not large enough for a human being to pass. The upper entrance is on the south side, whereas the lower one is situated in the bottom of the doline. The altitude difference of the openings is $12.3 \mathrm{~m}$ 


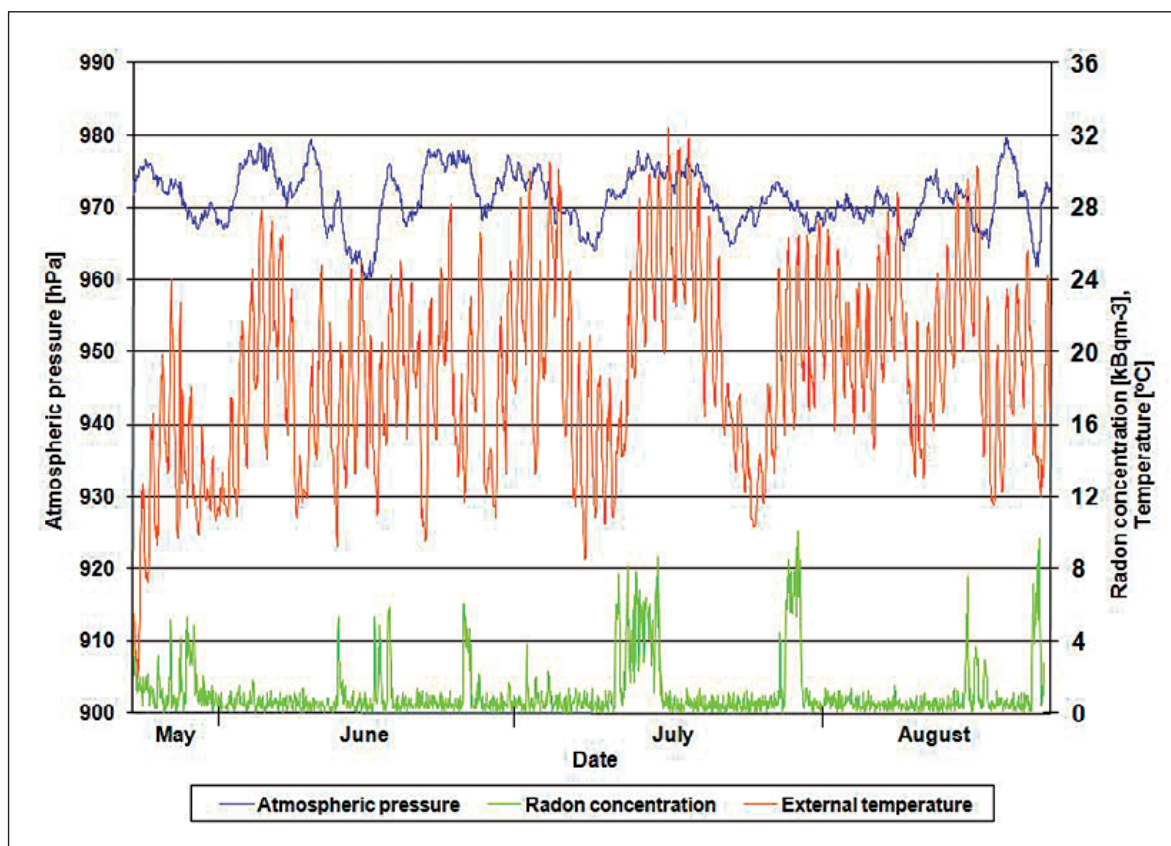

Fig. 5: Radon measurements at the entrance of Upper Szajha Cave compared with external temperature and atmospheric pressure, 2004.

mained permanently low, moreover showing even lower values than in summer (Fig. 6). Radon levels did not start to rise, even if the external temperature declined. In addition after the external temperature remained on a permanently low level all radon fluctuation exceeding $1 \mathrm{kBq} \mathrm{m}^{-3}$ stopped. While staying in the cave the following interest-

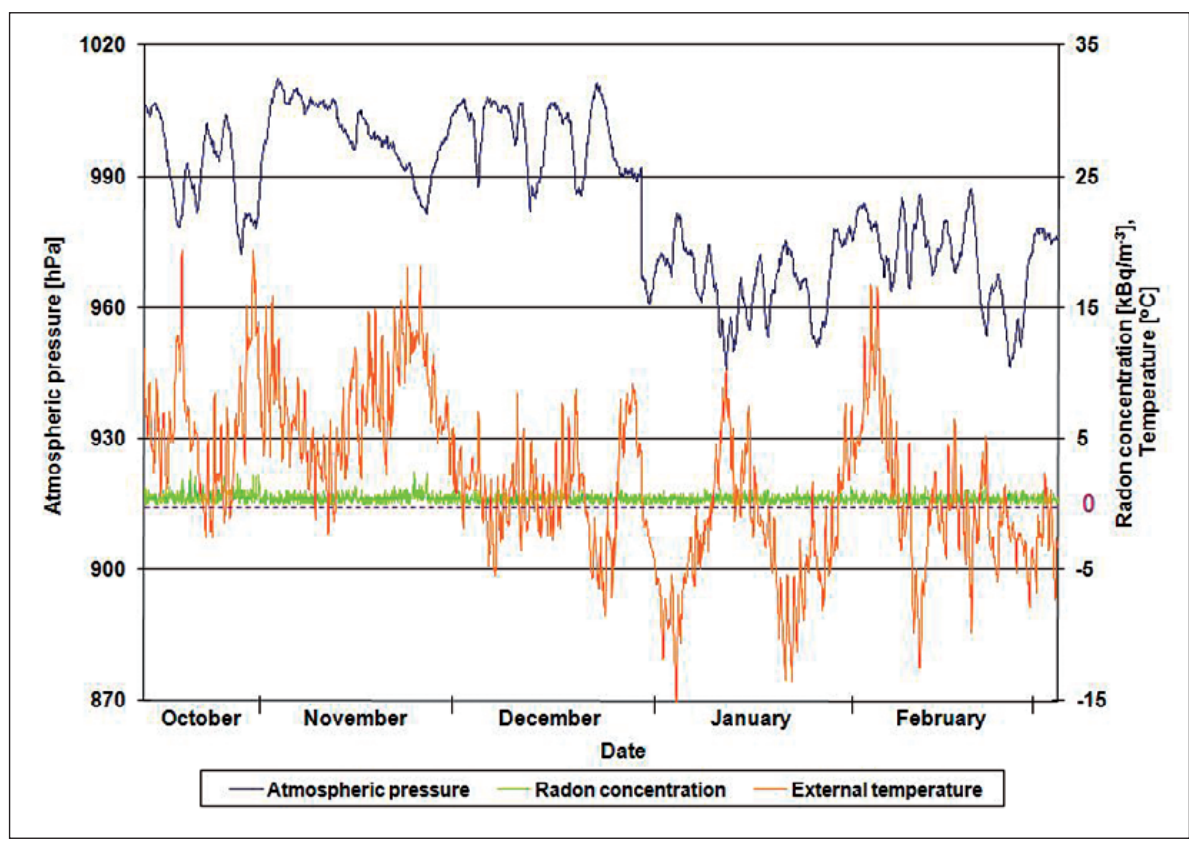

Fig. 6: Radon measurements at the entrance of Upper Szajha Cave compared with external temperature and atmospheric pressure, 2003-2004. ing phenomena were discovered concerning air migration: during both summer and wintertime the entrance of Upper Szajha Cave was characterized by an outward airflow; in summer air flowed from the current endpoint. In winter a strong cold airflow could be felt from the fissure where the two caves are connected; at the current endpoint air was going towards the unknown passages, and the entrance of Lower Szajha Cave was characterized by an inward airflow.

On the basis of our observations and radon concentration monitoring we have come to the conclusion that in wintertime the entrance of Lower Szajha Cave plays a dominant role in the ventilation of the cave. A dual airflow is generated by the air masses coming from Lower Szajha Cave: radon-poor air moves towards the current endpoint from the linkage of Lower Szajha Cave on the one hand, while on the other instead of an inward airflow an outward one develops at the entrance zone of Upper Szajha Cave. Consequently, low radon values were detected.

The high concentration spikes of the summer period suggested that the air convection system of Upper Szajha Cave was indirectly influenced by another pothole. Radon concentration rises only if the external temperature is beyond $9-12^{\circ} \mathrm{C}$ (Fig. 5), which shows that the two caves communicate via the unexplored lower passages. As the pothole is situated higher than Upper Szajha Cave it behaves like a hilltop cave. Consequently, if the external temperature is stable above $9-12^{\circ} \mathrm{C}$, radon-poor air sinks into the cave from the surface while reducing the radon concentration of 
Tab 3: The nature of radon concentration changes regarding caves in a hilltop position.

\begin{tabular}{|l|c|c|c|c|c|}
\hline $\begin{array}{l}\text { Name of the } \\
\text { cave }\end{array}$ & $\begin{array}{c}\text { Place of the } \\
\text { detector }\end{array}$ & Period & \multicolumn{2}{|c|}{$\begin{array}{c}\text { Mean }{ }^{222} R_{n} \text { concentration } \\
{\left[\mathrm{kBq} \mathrm{m}^{-3}\right]}\end{array}$} & $\begin{array}{c}\text { Measured }{ }^{222} \mathrm{Rn} \\
\text { (maximum } / \text { minimum) } \\
{\left[\mathrm{kBq} \mathrm{m}^{-3}\right]}\end{array}$ \\
\cline { 4 - 6 } & & summer & winter & $169(16.9 / 0.1)$ \\
\hline Pietró & entrance zone & $1995-2005$ & $2.5-3$ & $7-8$ & $200(20 / 0.1)$ \\
\hline Tüskés & entrance zone & $2002-2005$ & 2 & $6-7$ & $(20)$ \\
\hline
\end{tabular}

the unknown lower passage. When the external temperature goes beyond the critical rate, the draught inside the cave stops and changes its direction while enabling the increase of radon concentrations in the lower passage. In this case a radon-rich air comes to the system of Upper Szajha Cave and high concentration levels are recorded at the measuring point. On account of previous radon transport measurements (Zalán 1998), this unique phenomenon might be generated by Csiga Shaft.

Based on the latest exploration results, it can be ascertained that the airflow of Upper Szajha Cave is influenced by a higher positioned breakdown or depression that is definitely in connection with the $6 \mathrm{~m}$ high dome located at the current endpoint. In order to be able to perfectly reveal the complex convectional rules of the cave we would like to do comprehensive micro-climatic research.

\section{Vadetetős Cave}

Vadetetős Cave has been under investigation since November 2003. At that time the cave was only a few metres long; since then several new parts have been explored. In May 2007 measurements started at the end zone of the cave, as well. The recorded data showed that while between 2003 and 2006 radon concentration levels exceeded $40 \mathrm{kBq} \mathrm{m}^{-3}$, since February 2006 they have rarely gone above $30 \mathrm{kBq} \mathrm{m}^{-3}$. During the research, the highest values were measured in this cave. Between the middle of March and end of April in 2005, radon concentration exceeded $30 \mathrm{kBq} \mathrm{m}^{-3}$ five times: it reached $40 \mathrm{kBq} \mathrm{m}^{-3}$ once, $50 \mathrm{kBq}$ $\mathrm{m}^{-3}$ twice and $64 \mathrm{kBqm}^{-3}$ once. Air pressure variations were the major control parameter of radon level changes. The spikes on the graphs occurred when the internal pressure was low (Fig. 7).

As far as high and low periods are concerned Vadetetös Cave was characterized by remarkable differences between low summer and high winter periods before 2006. Since then the difference between summertime and wintertime is less significant (Tab. 2). The mean value of summer data was $3.6 \mathrm{kBqm}^{-3}$ in 2004 and $2.3 \mathrm{kBqm}^{-3}$ in 2005 , while the winter period of 20032004 was characterized by $16.5 \mathrm{kBq} \mathrm{m}^{-3}$, and in the following year it was $15.1 \mathrm{kBq} \mathrm{m}^{-3}$. Despite the fact that between 1 December 2005 and 28 February 2006 radon concentration reached $44.2 \mathrm{kBq} \mathrm{m}^{-3}$ once and exceeded $15 \mathrm{kBq} \mathrm{m}^{-3}$ twice more, the mean value of the recorded data remained on a surprisingly low level $\left(2.9 \mathrm{kBq} \mathrm{m}^{-3}\right)$. Unfortunately, there was no monitoring during the next winter. In 2007 the mean winter values were about $2 \mathrm{kBq} \mathrm{m}^{-3}$. $\mathrm{Nev}$ ertheless as a result of being less affected by the changes of the external and internal air, the current endpoint is characterized by higher radon concentration. In winter it was characterized by a mean value of $17 \mathrm{kBq} \mathrm{m}^{-3}$, while in summer the mean levels were only $7.8 \mathrm{kBq} \mathrm{m}^{-3}$. 


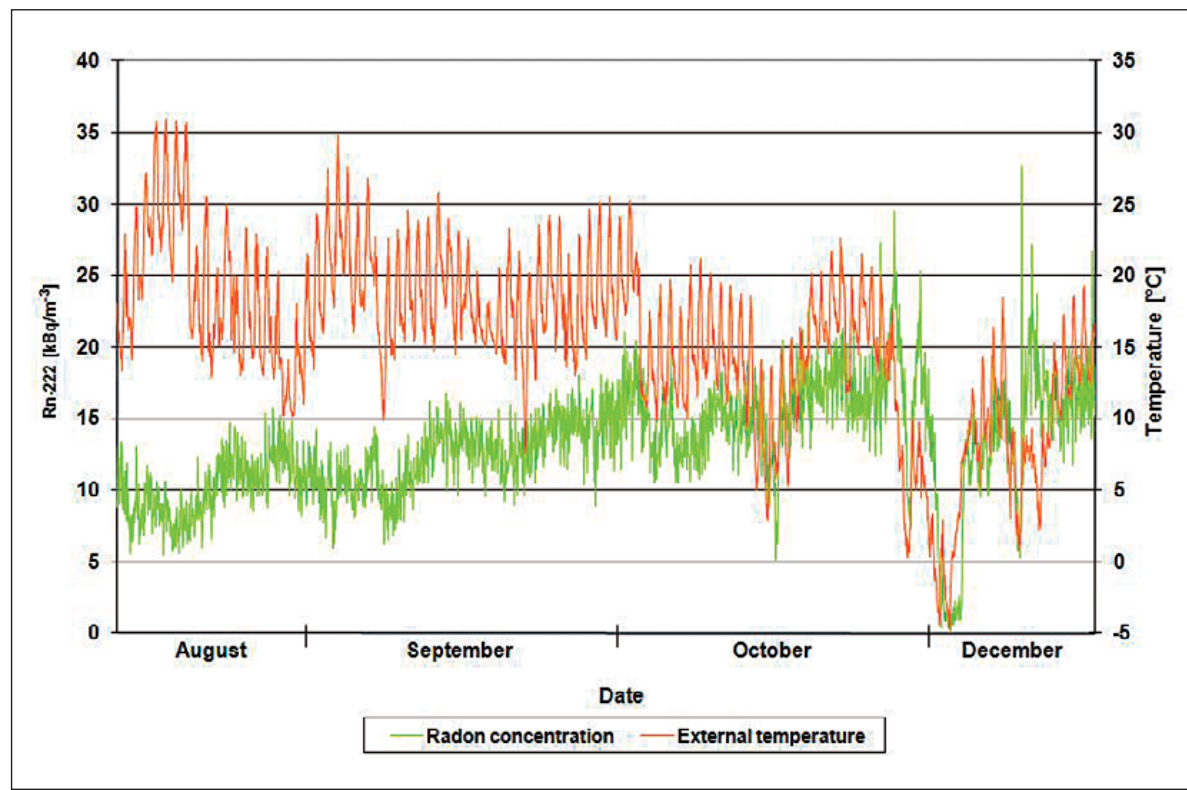

Fig. 8: Radon measurements at the entrance of Vadetetös Cave compared with external temperature, 2006.

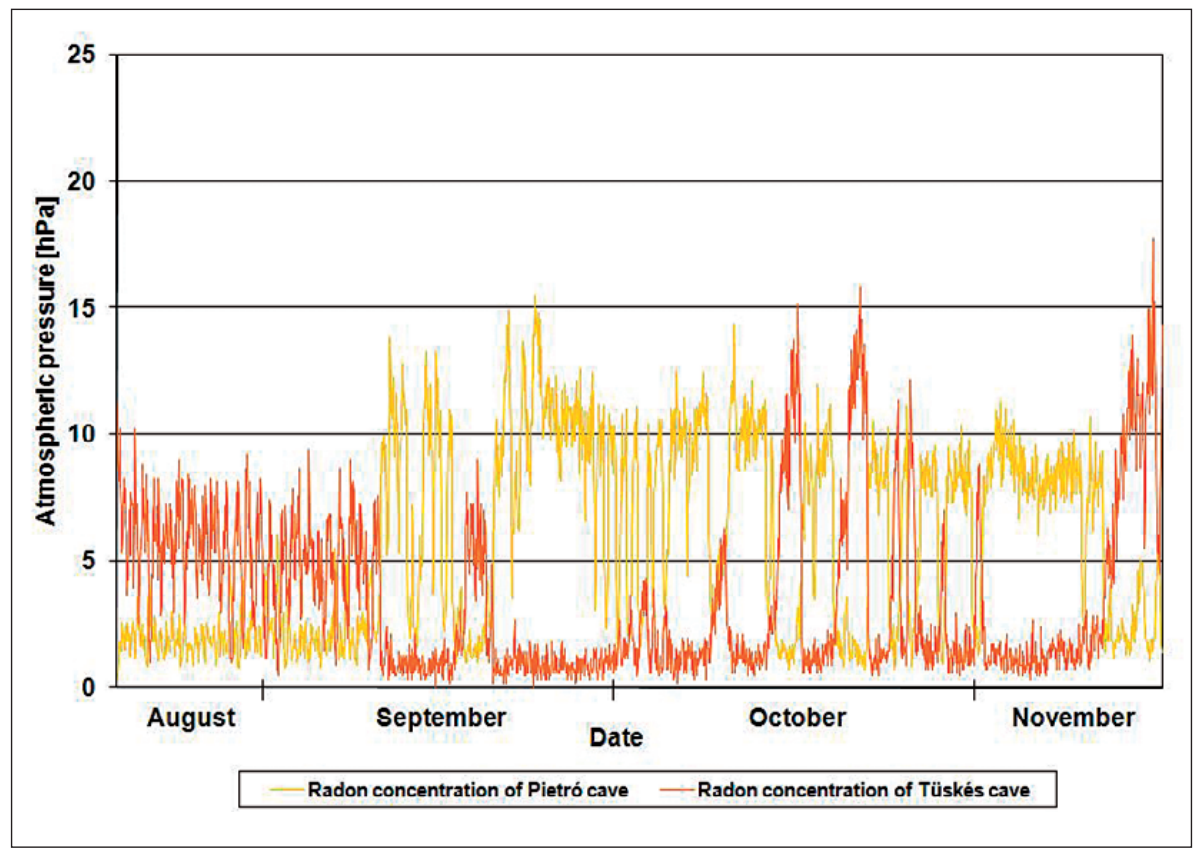

Fig. 9: Radon measurements at the entrance zones of Tüskés and Pietró caves, 2002.

its convectional system is complicated. Regarding the relationship of external temperature and internal radon concentration, turning points can be observed. For instance before 3 December 2003 radon levels directly followed the fluctuation of external temperature. Afterwards radon concentration rose if external temperature went beyond $9-12^{\circ} \mathrm{C}$. On the contrary, the opposite happened in September 2006 (Fig. 8). Even so, there were periods when the connection between the variation in radon levels and external temperature was ambiguous. These direction changes might be caused by an air connection with another cave, which has an upper position and opens up for shorter or longer periods. A small passage or a siphon might unfold.

\section{CAVES IN A HILLTOP POSITION}

The entrances of Pietró and Tüskés caves are situated on the top of a hill. By having their entrances only $94 \mathrm{~m}$ apart from each other with a 7,3 m height difference, these caves are very interesting.

The long-term measurements between 1995 and 2005 did not reveal any significant changes. The radon concentrations of the two caves change conversely

Atmospheric pressure dominantly governed the fluctuation of radon concentration in Vadetetős Cave. The influencing factor of temperature change was less significant. Nevertheless, the previously described changes might be connected either to some results in excavational research or to the opening of another breakdown. Though the cave is relatively small, to each other (Fig. 9); consequently the two caves might have a shared convection system. In order to prove this, the entrance of Tüskés Cave was artificially closed between $11^{\text {th }}$ January and $9^{\text {th }}$ February in 2003. Unfortunately, the sealing of the entrance was imperfect (Zalán 2004). Concerning radon concentration no remarkable changes happened during the closure. 


\section{SUMMARY}

In general, it can be concluded that the radon concentration of caves situated in the Mecsek Mountains is particularly high. As a result of their morphological position the highest values were measured in caves having their entrances on a valley floor, while the lowest concentration levels are connected to caves which open up on the top of a hill. Interestingly, the highest momentary radon concentration was measured in Vadetetős Cave. The source of these high local levels, which are exceeding the Hungarian mean values, can be on the one hand the nearly 50-year-long immission stress of uranium mining and on the other hand the closeness of sandstone beds containing uranium.

Concerning the convectional systems of the investigated caves, we could detect that the entrance zone of Szuadó Cave was characterized by inverse functioning in 2007, which might be caused by chimney effect. More- over, Sára Spring was characterized by rather high concentration levels. In order to mark off the exact sources of these high radon values we would like to carry out further water and air examinations.

In the case of Upper Szajha Cave it can be stated that in winter Lower Szajha Cave plays a dominant role in the ventilation of the cave while in summer it is most probably influenced by another breakdown. As far as Vadetetös Cave is concerned it can be ascertained that besides remarkable concentration variations, the direction of airflow changed during the measurement period. In order to provide answers for the emerging questions we would like to do comprehensive microclimatic research in these caves. These measurements would include the analyses of the following parameters: internal temperature, internal pressure, underground airflow, $\mathrm{CO}_{2}$ and radon concentration.

\section{ACKNOWLEDGEMENTS}

The authors would like to express their thanks to Béla Zalán for his help and to Mecsekérc ZRT for providing the radon detectors.

\section{REFERENCES}

Barta, K. \& T. Tarnai, 1999: Karstmorphological research in the Mecsek Mountains, South Hungary.- Acta Carsologica, 28,1, 13-26.

Dezső, Z. \& L. Molnár, 2001: Barlangkutatás radonnal.In: Sásdi, L. (ed.) Professional Meeting of Hungarian Speleologists, $27^{\text {th }}-29^{\text {th }}$ October 2000 , Pécs. PTEMKBT, 84-90, Pécs.

Dezső, Z., Hakl, J. \& L. Molnár, 2001: Barlangi kőzetek radon exhalációja III.- In: Veress, M. (ed.) Karst Development Conference, $6^{\text {th }}-7^{\text {th }}$ April 2001, Szombathely. BDF, 305-313, Zalaegerszeg

Fülöp, J., 1994: Magyarország geológiája II.- Akadémiai Kiadó, Budapest, 359-375.

Hakl, J., Hunyadi, I. \& A. Várhegyi, 1997a: Radon monitoring in caves.- In: Duranni, S. A. \& R. Ilic (eds.) Radon Measurements by Etched Track Detectors Applications in Radiation Protection, Earth Sciences and the Environment, World Scientific Publishing Co., pp. 261-268, Singapore.
Hakl, J., 1997: Application of Radon-222 as a Natural Tracer in Environmental Studies.- PhD thesis. Lajos Kossuth University Debrecen, pp. 30.

Hakl, J., Hunyadi, I., Csige, I., Géczy, G., Lénárt, L. \& A. Várhegyi., 1997b: Radon Transport Phenomena Studied in Karst Caves- International Experiences on Radon Levels and Exposures.-

Radiation Measurements, 28, 1-6, 675-684.

Papp, B., Deák, F., Horvát, Á., Kiss, Á. \& G. Vid, 2004: A barlangi agyagos kitöltés radon viszonyainak vizsgálata a Baradla-barlang egy pontján.- In: Veress, M. (ed.) Karst Development Conference, $19^{\text {th }}$ - 20 ${ }^{\text {th }}$ March 2004, Szombathely. BDF, 321-328, Zalaegerszeg.

Zalán, B., 1998: Radonmérések néhány mecseki barlang bejáratánál.- Pro Natura Karst- and Cave Research Group, Report of the Research Year 1997, 20-26.

Zalán, B., 2004: Radontranszportmérések négy mecseki barlangban.- Pro Natura Karst- and Cave Research Group, Report of the Research Year 2004, 30-37. 